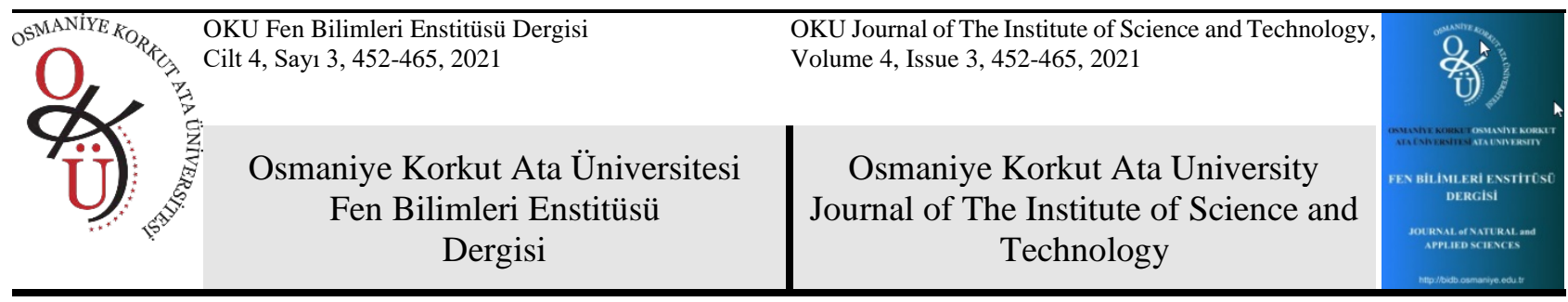

\title{
Enerji Tüketimi ve Ekonomik Büyüme İlişkisi: Türkiye
}

Bülent YANIKTEPE ${ }^{*}$, Tennur KISAKÜREK PARLAK ${ }^{2}$, Osman KARA ${ }^{3}$

${ }^{1}$ Osmaniye Korkut Ata Üniversitesi, Enerji Sistemleri Mühendisliği Bölümü, 80010, Osmaniye

${ }^{2}$ Osmaniye Korkut Ata Üniversitesi, Düziçi Meslek Yüksekokulu, 80600, Osmaniye

${ }^{3}$ Osmaniye Korkut Ata Üniversitesi, Enerji Sistemleri Mühendisliği Bölümü, 80010, Osmaniye

${ }^{1}$ https://orcid.org/0000-0001-8958-4687

${ }^{2}$ https://orcid.org/0000-0002-9721-4528

${ }^{3}$ https://orcid.org/0000-0003-1501-677X

*Sorumlu yazar: byaniktepe@osmaniye.edu.tr

\section{Araştırma Makalesi \\ ÖZET}

Makale Tarihçesi:

Geliş tarihi: 18.07.2021

Kabul tarihi:22.10.2021

Online Yayınlanma: 15.12.2021

\section{Anahtar Kelimeler:}

Ekonomik büyüme

Enerji tüketimi

Nedensellik
Bir ülkenin yaşam standardı ve büyümesindeki yükseliş enerji tüketimini artırmakta ve tüketimin ihtiyacının artması da ekonomik büyümeyi etkilemektedir. Her ülke kendi gelişmişliğine göre farklı tepkiler sergilese de çalışmalar enerji tüketimi ve ekonomik büyüme etkileşiminin oldukça kuvvetli olduğunu desteklemektedir. 1970-2015 dönemine ait enerji tüketimi verileri kullanılarak yapılan bu araştırmada, enerji tüketimi ve ekonomik büyüme ikilisi üzerine inceleme yapılmıştır. Bağımlı değişken, reel Gayri Safi Yurt İçi Hasıla (GSYH) ve bağımsız değişken enerji tüketimidir. Birim kök durumunun incelenmesi amacıyla Genişletilmiş DickeyFuller (ADF) ve Phillips-Perron (PP) testleri uygulanmıştır. Birim kök analizinin ardından, değişkenlerin uzun dönemde dengeye gelip gelmediğini ortaya çıkartmak için Johansen eş bütünleşme testi yapılmıştır. Son adım olarak, model için değişkenler arasında eşbütünleşme bulduktan sonra nedensellik test edilmiştir. Yapılan nedensellik analiz sonucunda enerji tüketimi ve ekonomik büyüme arasında pozitif yönlü bir ilişki olduğu bulunmuştur.

\section{Relationship between Energy Consumption and Economic Growth: Turkey}

\section{Research Article}

Article History:

Received: 18.07.2021

Accepted: 22.10.2021

Published online: 15.12.2021

\section{Keywords:}

Economic growth

Energy consumption

Causality

\begin{abstract}
The rise in the living standard and growth of a country increases energy consumption, and the increase in consumption needs also affects economic growth. Although each country reacts differently according to its own development, studies support that the interaction of energy consumption and economic growth is quite strong. In this study, which was conducted using energy consumption data for the period 1970-2015, an examination was made on the couple of energy consumption and economic growth. The dependent variable is real Gross Domestic Product (GDP) and the independent variable is energy consumption. Augmented DickeyFuller (ADF) and Phillips Perron (PP) tests were applied to examine the unit root state. After the unit root analysis, Johansen cointegration test was performed to find out whether the variables are in equilibrium in the long run. As a final step, causality was tested after finding cointegration between the variables for the model. As a result of the causality analysis, it was found that there is a positive relationship between energy consumption and economic growth.
\end{abstract}

To Cite: Yanıktepe B., Parlak TK., Kara O. Enerji Tüketimi ve Ekonomik Büyüme İlişkisi: Türkiye. Osmaniye Korkut Ata Üniversitesi Fen Bilimleri Enstitüsü Dergisi 2021; 4(3): 452-465.

\section{Giriş}

Enerji; üretim sürecinden tüketime kadar etkin kullanılması gereken ve geçmişten günümüze hem bireyleri hem de toplumları ilgilendiren ve etkileyen bir ekonomik kaynak olarak etkisini sürdürmektedir. Geçmiş 
dönemlerden bu yana çeşitli alanlarda var olan enerji, 19. yüzyılın ortalarında halkın ihtiyaçlarını karşılamaya yetmekteydi. Bu zaman diliminden sonra ortaya çıkan Petrol krizi hem siyasi olarak hem de ekonomik açıdan enerjinin çok önemli olduğunu göstermektedir. Hızla artan nüfus, sanayileşme ve kentleşmenin sonucu olarak artan enerji tüketimi nedeniyle enerji fiyatlarında artış yaşanmaktadır. Petrol ihraç eden ülkeler ile Amerika Birleşik Devletleri arasında yaşanan bu Petrol krizinin etkileri kısa sürede dikkat çekici olmuştur. Petrol fiyatlarının katlanarak artış göstermesi petrol ihraç eden ülkeleri siyasi, sosyal ve ekonomik olarak etkilemiştir (Korkmaz ve Develi, 2012).

Üretim faaliyetlerinde azalmalar ve maliyetlerde artışlar meydana gelmiş, bu durumlarda enerji tüketicilerini olumsuz etkilemiş̧ir. 1973 Petrol Krizi, gelişmiş ve gelişmekte olan ülkelerin ekonomilerinde daralmalar yaşanmasına ve bunun sonucunda durgunluk dönemine neden olmuştur. Bu dönemden sonra ülkeler elinde olan konvansiyonel enerji kaynaklarını korumaya ve yenilenebilir enerji kaynaklarının kullanımını artırmaya yönelik tasarruf artırıcı bazı politikalara yer vermektedir (Öztürk ve Saygın, 2017).

Türkiye'yi ele aldığımızda enerji tüketiminde özellikle sanayi ve ulaşım sektörleri sıralamada önde yer almaktadır. Enerji tüketimimiz üretime göre artış göstermektedir. Bu bağlamda, enerjinin tüketim ile ekonomik göstergeler arasındaki nedenselliğinin yönü genel olarak Granger (Granger, 1969) nedenselliği ile açıklanmaya çalışılmaktadır. Granger’in geliştirmiş olduğu bu teknik sayesinde, Granger nedenselliği üzerine bu alandaki kaynaklar önemli derecede gelişmektedir. Uygulamalı araştırmalar için ise çalışmalarda, ekonomik büyüme ve enerji tüketimi ikilisi arasındaki nedensellik sorunu ele alınmaktadır.

Literatürde bazı çalışmalarda, enerji tüketim değişkeninden ekonomik büyüme değişkenine doğru ya da ekonomik büyüme değişkeninden enerji tüketim değişkenine doğru çift yönlü bir bağ bulunurken (Shakeel ve ark., 2013), bazılarında ise tek yönlü bağ (Şengül ve Tuncer 2006; Yanar ve Kerimoğlu, 2011; Aslan, 2013; Pao ve ark., 2014; Bhattacharya ve ark., 2016), diğerlerinde (Yalta, 2011) ise herhangi bir yönde nedenselliğin olmadığı saptanmıştır. Araştırılan bu sonuçlar aynı ülkeler ve ele alınan zaman aralığında birbirine yakın girdi değerleri olmasına rağmen kullanılan tahmin yöntemlerine bağlı olarak değiştiği gözlemlenmektedir.

Gelişmişte olan ülkeler enerji kullanımında çeşitli enerji türlerine geçmeye başlamaktadır. Ülkenin içinde bulunduğu coğrafyası, nüfusu, kırsal kesim ile şehir merkezleri arasındaki nüfus dağılımı enerjinin tüketilmesini etkilemektedir. Bir ülkedeki gelir düzeyi, o ülkenin enerjiyi talep etmesi ve bunun doğrultusunda enerji arzının sağlanmasında oldukça önemli bir unsurdur. Genel anlamda enerjinin tüketim değerleri ile ekonomik büyüme rakamları arasında çift taraflı bir ilişki vardır. Bir ülke için ekonomik büyümenin olması enerji tüketim rakamlarını artırmakta, enerji tüketim rakamları ise ekonomik büyümeyi etkilemektedir.

\section{Türkiye'de Enerji Üretim-Tüketim Durumu}

Türkiye’nin kurulu gücü, 2021 Nisan itibarıyla 97,3 GW'a ulaşmıştır. Şekil 1'de Elektrik enerjisi üretiminin kaynaklara göre dağılımına baktığımızda; en çok payı \%21,69 ile barajı hidroelektrik santralleri ve sonrasında sırasıyla ithal kömür \%19,87, doğal gaz \%18,85, Linyit \%15,42 almaktadır. Şekil 2’ye göre yenilenebilir enerji kaynaklarından elektrik enerjisi üretiminde rüzgâr, güneş ve jeotermal enerjinin payları sırasıyla; \%16,43, \%6,99 ve \%6,77’dir (TEİAŞ, 2021). 
Enerjiye olan ihtiyaç, geçmişten günümüze artarak devam etmektedir. Şekil 3 ve 4 'te görüldügü üzere Türkiye’nin, 1990'dan bu yana genel itibariyle enerji tüketiminde artış sağladığı görülmektedir. Enerji tüketiminin artmasıyla birlikte enerji üretiminde de artış meydana gelmiştir ve bu değer 2018 yılında 65 Milyon TEP, 2019 yılında yaklaşık 70 Milyon TEP’tir. Toplam enerji tüketim değerine baktığımızda 1990'lı yıllardan günümüze artarak devam etmekte olup, 2018 yılında 150 Milyon TEP, 2019 yılında ise bu rakam 155 Milyon TEP’tir (Global energy statistical yearbook, 2020).

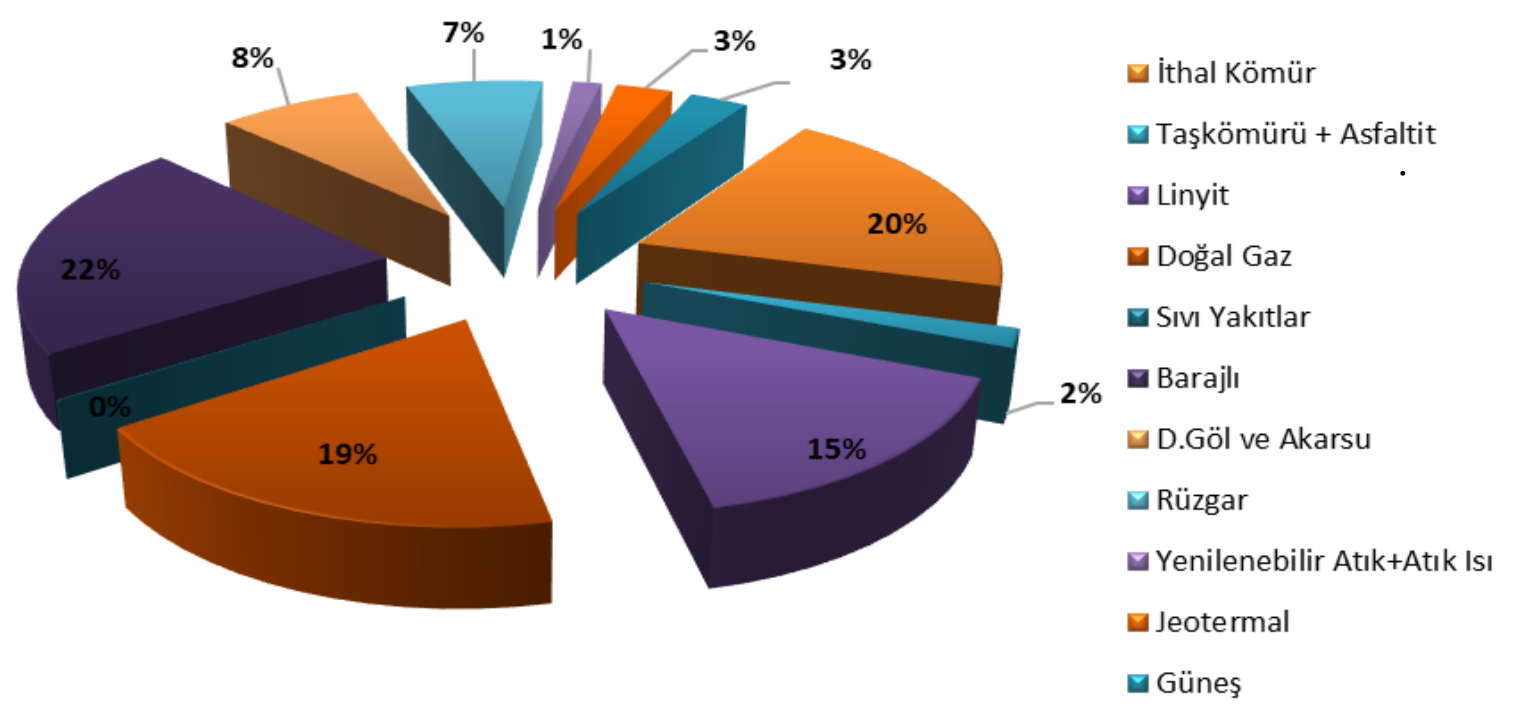

Şekil 1. Türkïye Elektrik Enerjisi Üretiminin Kaynaklara Göre Dağılımı

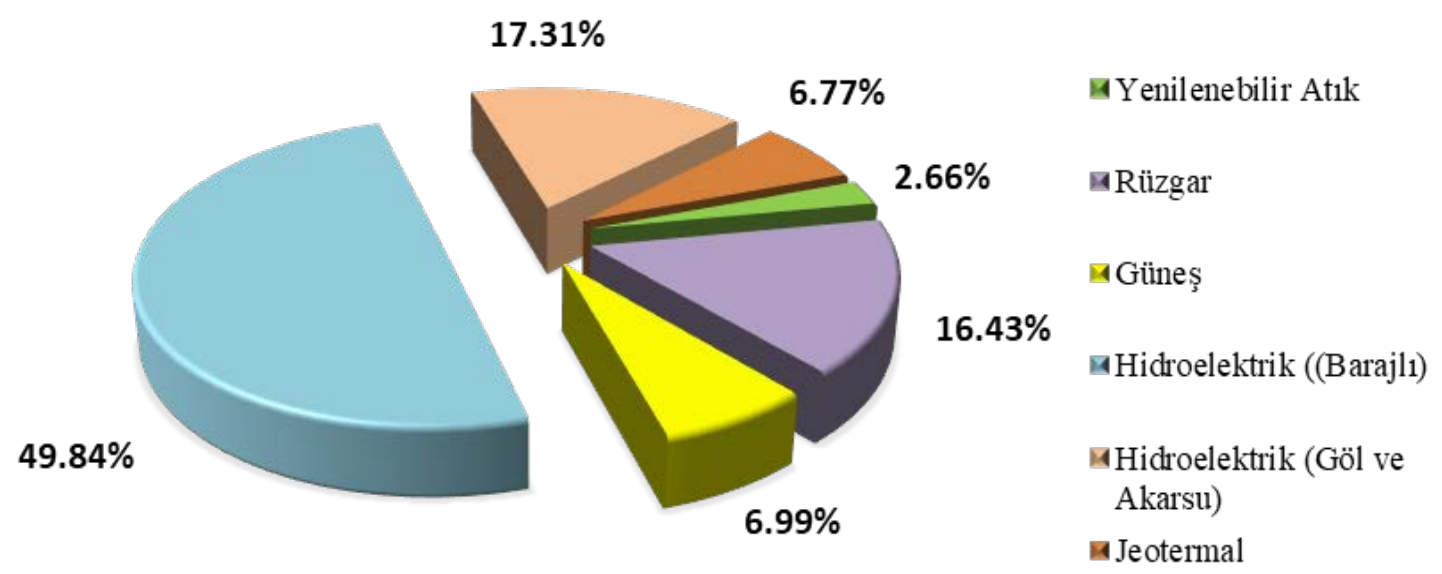

Şekil 2. Yenilenebilir enerji kaynakları ile elektrik enerjisinin sağlanması 


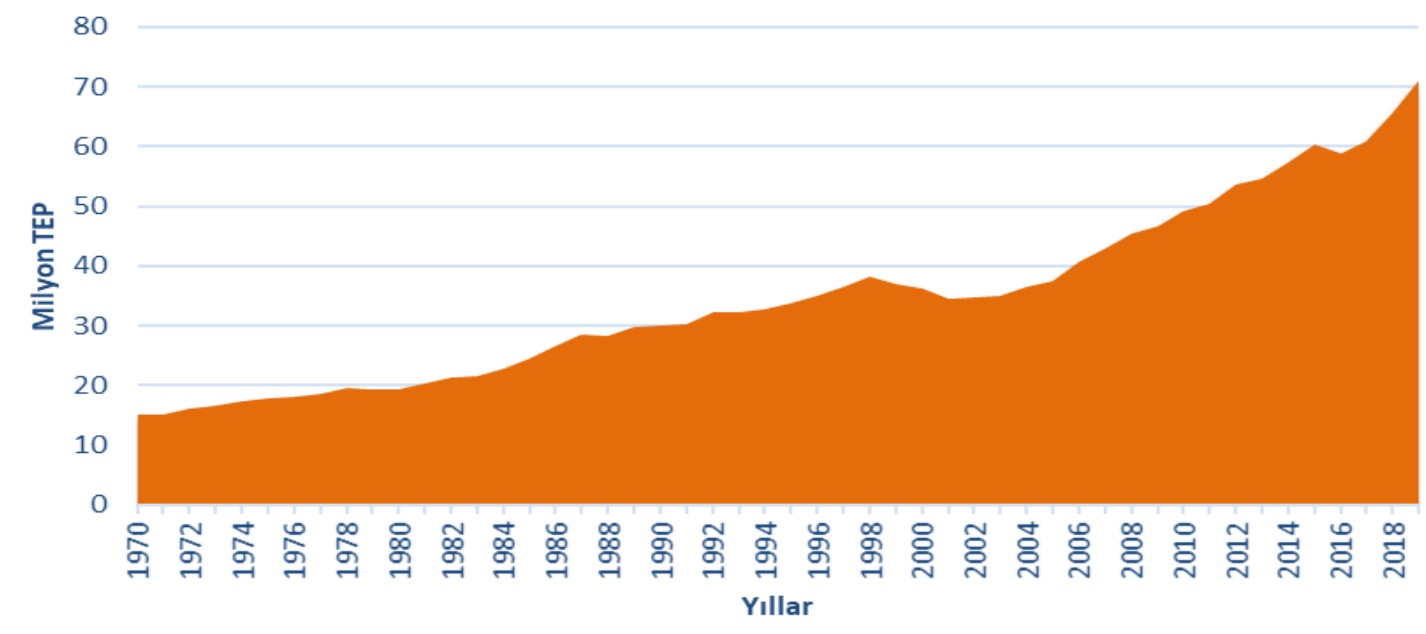

Şekil 3. Yıllara Göre Türkiye Toplam Enerji Üretimi

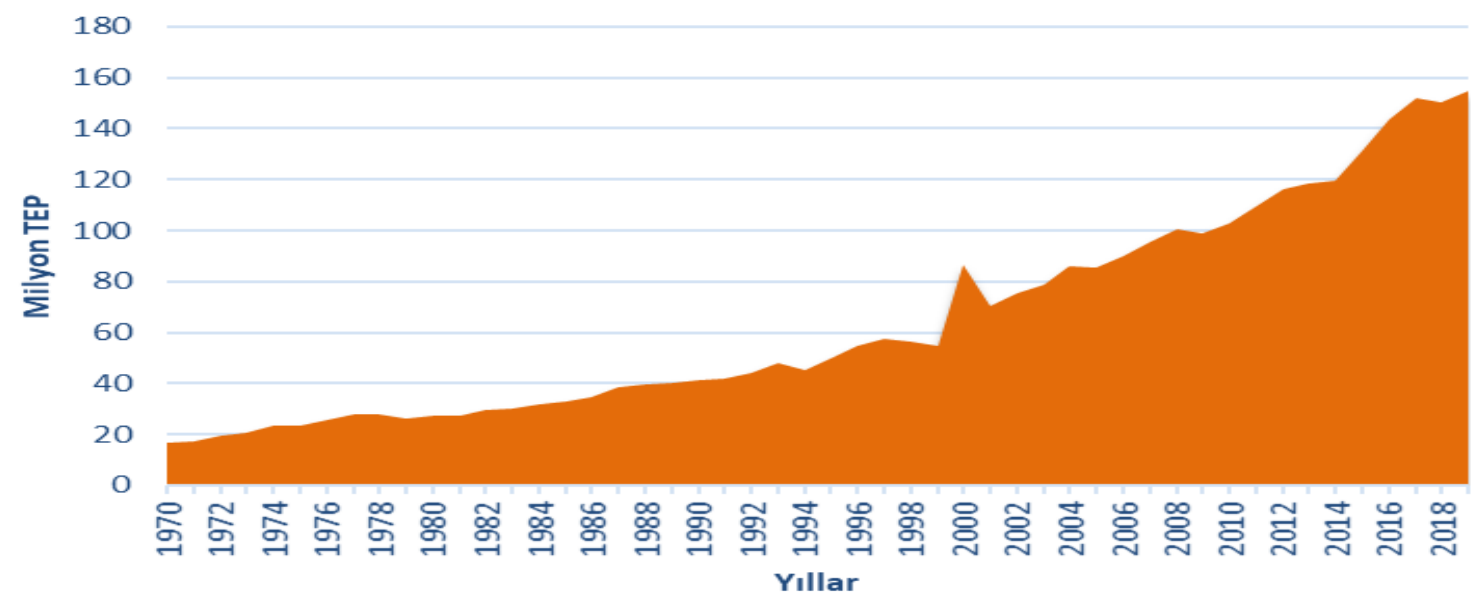

Şekil 4. Türkiye 1990-2019 Yılları Arasında Toplam Enerji Tüketimi

Ekonomik büyüme ile enerji tüketimi değişkenlerinin incelenmesine ilişkin birçok araştırma yapıldığı, ilgili iki değişken arasındaki nedensellik ilişkisinin araştırılması dikkat çekmektedir. Enerji ve ekonomik büyüme ilişkisinin araştırılmasına öncülük eden Kraft ve Kraft (1978), gerçekleştirmiş olduğu çalışmalarında enerji tüketimi ile ekonomik büyüme arasındaki bağlantının varlığının nasıl belirlendiğini açıklamışlardır.

Türkiye için 1960-2000 dönemi verilerini kullanarak (Şengül ve Tuncer, 2006) ticari enerji kullanımı, reel enerji fiyatları ve GSYH verileri arasındaki nedenselliği bulmaya çalışmışlardır. Yapılan birim kök testleri ve Granger nedensellik testi sonucunda ticari enerji kullanımından GSYH’ye doğru tek yönlü bir nedensellik bulmuşlardır.

Demirbaş ve ark., (2009), Türkiye'ye ilişkin cari açık ve petrol fiyatlarını araştırmışlardır. 1984-2008 yıllık verileri doğrultusunda gerçekleştirilen analiz Augmented Dickey-Fuller (ADF), eş bütünleşme analizleri, Vektör Hata Düzeltme Modeli (VECM) ile sağlanmıştır. Petrol fiyatlarında ortaya çıkan yükselişin cari açığ 1 artırdığ 1 görülmüştür. 
Tsani (2010), 1960-2006 yıllar arasında Yunanistan için sektör bazlı enerji tüketimi ve ekonomik büyüme üzerine çalışma yapmıştır. Yöntem olarak Granger nedensellik ve vektör hata düzeltme model analizini uygulamışlardır. Ulaşım ve sanayi sektörü yerleşik bölge enerji tüketim bazında araştırma yapmıştır. Türkiye'ye ilişkin yapılan başka bir çalışmada, 1950 ile 2006 zaman aralığında Türkiye ekonomisine ilişkin eşbütünleşme analizi gerçekleştirilmiştir. Daha sonra istihdam rakamları da veri setine dahil edilmiştir. Çalışma sonucunda enerji tüketimi ile GSYH arasında bir bağ tespit edilememiştir (Yalta, 2011).

Kerimoğlu ve ark., (2011), Türkiye için yapmış oldukları araştırmada 1975-2009 yılları zaman diliminde ekonomik büyüme, enerji tüketimi ve cari açık ilişkisini incelemişlerdir. Cari açık ve enerji tüketiminin üzerinde nasıl bir etki gösterdiğini eş bütünleşme testi ve VECM kullanarak araştırmışlardır. Çalışma sonucuna göre enerji tüketiminden ekonomik büyümeye doğru kuvvetli bir ilişki bulurken cari açık ile büyüme arasında çift yönlü zayıf ilişki tespit etmişlerdir. Güney Asya ekonomileri için ele alınan bir çalışmada, 1980-2009 yılları arasındaki zaman veri setini kullanarak enerji tüketimi, reel GSYH ve ticaret değişkenleri arasındaki ilişkileri incelemek amacıyla panel eş bütünleşme testine yer vermişlerdir. Çalışma sonucunda, kısa dönemde değişken olarak kullanılan enerji tüketimi ve reel GSYH değişkenine ilişkin çift taraflı fayda sağlandığına ulaşmıştır. Uzun dönemde ise bu iki değişken arasında yine aynı sonuca ulaşmıştır. İhracat değişkeninden enerji tüketimi değişkenine doğru tek taraflı nedenselliğe ulaşmışlardır (Shakeel ve ark., 2013).

OECD 22 ülke için en küçük kareler (EKK) ile dinamik EKK metotlarını uygulayarak enerji tüketim ve GSYH bağıntısını incelemiştir. Araştırmaya göre, enerji tüketim değişkeninden GSYH değişkenine doğru nedenselliğin yalnızca Portekiz ile İzlanda'da bulunduğunu fakat genel olarak GSYH'den enerji tüketimi değişkenine doğru oldukça anlamlı bir ilişki olduğu saptamıştır (Aslan, 2013). Brezilya için enerji tüketim değerleri ve ekonomik büyüme ilişkisini, 1980-2008 yılarında dağılımını ele almışlardır (Pao ve ark., 2014). Enerji tüketim değerleri ile GSYH ilişkisinin pozitif yönlü olduğunu ve uzun dönem dengesinde enerji tüketim değerlerinden ekonomik büyümeye doğru yine pozitif bir etki olduğunu vurgulamışlardır.

Türkiye'ye ilişkin 1970-2014 yıllarını baz alarak enerji tüketim değişkeni ile GSYH bağını incelemek adına eşbütünleşme analizi ve dinamik en küçük kareler metodunu kullanmışlardır (Gövdere ve Can, 2015). Araştırma sonucunda bu değişkenler arasında uzun dönem ilişkisinin mevcut olduğunu bulmuşlardır. Bhattacharya ve ark., (2016), 1991-2012 dönemi yılları aralığında, en çok yenilenebilir enerji tüketen 38 ülke için ekonomik büyüme ilişkisini incelemişlerdir. Sonuçlara göre seçilen ülkelerin yarısından fazlasında enerji tüketiminden ekonomik büyümeye doğru pozitif bir etki tespit etmişlerdir.

Literatürde bulunan bazı çalışmalar, verilerin kapsadığı dönem, kullanılan değişkenler, kullanılan metot ve sonuçlar şeklinde kıyaslamalar Tablo 1'de yapılmıştır. 
Tablo 1. Enerji tüketimi ile ekonomik büyüme arasındaki ilişkiye ait bazı literatür çalışmalarının kıyaslanması

\begin{tabular}{|c|c|c|c|c|}
\hline Yazar(lar) & $\begin{array}{l}\text { Verilerin } \\
\text { Kapsadığı } \\
\text { Dönem }\end{array}$ & Kullanılan Değişkenler & Kullanılan Metot & Sonuçlar \\
\hline $\begin{array}{l}\text { Şengül ve } \\
\text { Tuncer, } 2006\end{array}$ & $1960-2000$ & $\begin{array}{l}\text { - Ticari Enerji Kullanımı } \\
\text { - Reel Enerji Fiyatları } \\
\text { - GSYH }\end{array}$ & $\begin{array}{l}\text { - Augmented Dickey } \\
\text { Fuller Testi } \\
\text { - Toda ve Yamamoto } \\
\text { - Granger Nedensellik } \\
\text { Analizi }\end{array}$ & $\begin{array}{l}\text { Enerji kullanımından GSYH'ye tek yönlü } \\
\text { nedensellik tespit etmişlerdir. }\end{array}$ \\
\hline
\end{tabular}

\begin{tabular}{|c|c|c|c|c|c|}
\hline $\begin{array}{l}\text { Demirbaş } \\
\text { ark., } 2009\end{array}$ & ve & 1984-2008 & $\begin{array}{l}\text { - Türkiye Petrol Fiyatları } \\
\text { - Cari Açık }\end{array}$ & $\begin{array}{l}\text { - Augmented Dickey } \\
\text { Fuller Testi } \\
\text { - Eş bütünleşme testi } \\
\text { - VECM }\end{array}$ & $\begin{array}{l}\text { Türkiye petrol fiyatında artış olması cari açığın } \\
\text { artmasına neden olduğu sonucunu bulmuşlardır. }\end{array}$ \\
\hline
\end{tabular}

\begin{tabular}{|c|c|c|c|c|}
\hline Tsani, 2010 & $1960-2006$ & $\begin{array}{l}\text { - Ekonomik Büyüme } \\
\text { • Enerji Tüketimi }\end{array}$ & $\begin{array}{l}\text { - Granger nedensellik } \\
\text { analizi } \\
\text { - Vektör otokorelasyon } \\
\text { yöntemi }\end{array}$ & $\begin{array}{l}\text { Toplam enerji tüketiminden reel GSYH'ye doğru } \\
\text { nedensellik bulmuşlardır. }\end{array}$ \\
\hline Yalta, 2011 & $1950-2006$ & $\begin{array}{l}\text { - Enerji Tüketimi } \\
\text { - GSYH }\end{array}$ & - Eşbütünlesme testi & $\begin{array}{l}\text { Enerji tüketimi ile GSYH arasında bir ilişki } \\
\text { bulamamışlardır. }\end{array}$ \\
\hline
\end{tabular}

\begin{tabular}{|c|c|c|c|c|c|}
\hline $\begin{array}{l}\text { Kerimoğlu } \\
\text { ark., } 2011\end{array}$ & ve & $1975-2009$ & $\begin{array}{l}\text { - Ekonomik büyüme } \\
\text { - Enerji tüketimi } \\
\text { - Cari açık }\end{array}$ & $\begin{array}{l}\text { - Eşbütünleşme testi } \\
\text { - VECM }\end{array}$ & $\begin{array}{l}\text { Enerji tüketiminden ekonomik büyümeye doğru } \\
\text { kuvvetli bir ilişki bulurken cari açık ile büyüme } \\
\text { arasında çift yönlü zayıf ilişki tespit etmişlerdir. }\end{array}$ \\
\hline
\end{tabular}

\begin{tabular}{|c|c|c|c|c|}
\hline $\begin{array}{l}\text { Shakeel ve ark.., } \\
2013\end{array}$ & $1980-2009$ & $\begin{array}{l}\text { - Enerji Tüketimi } \\
\text { - Ticaret ve GSYH }\end{array}$ & $\begin{array}{l}\text { - Panel eşbütünleşme } \\
\text { analizi }\end{array}$ & $\begin{array}{l}\text { Enerji tüketimi ve reel GSYH değişkenine ilişkin } \\
\text { çift taraflı fayda sağlandığına ulaşmıştır. Uzun } \\
\text { dönemde ise bu iki değişken arasında yine aynı } \\
\text { sonuca ulaşmıştır. }\end{array}$ \\
\hline
\end{tabular}

\begin{tabular}{|c|c|c|c|c|}
\hline Aslan, 2013 & $1960-2005$ & $\begin{array}{l}\text { - Enerji Tüketimi } \\
\text { • Ekonomik Büyüme }\end{array}$ & $\begin{array}{l}\text { - Tam değiştirilmiş EKK } \\
\text { yöntemi } \\
\text { • Dinamik EKK yöntemi }\end{array}$ & $\begin{array}{l}\text { Genel olarak ekonomik büyümenin enerji } \\
\text { tüketimini kuvvetli, enerji tüketiminin ekonomik } \\
\text { büyümeye olan ilişkinin iki ülke için olduğunu } \\
\text { saptamıştır. }\end{array}$ \\
\hline
\end{tabular}

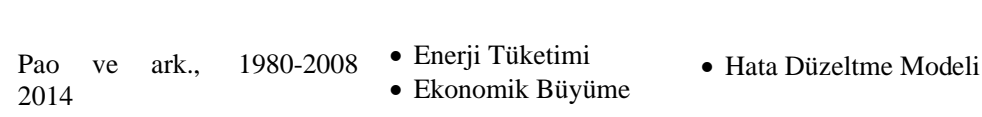

Brezilya için enerji tüketim değerleri ve ekonomik büyüme ilişkisini incelemişlerdir. Sonuç olarak, enerji tüketim değerleri ve ekonomik büyüme arasında pozitif bir tesir olduğunu ve uzun dönem dengesinde enerji tüketim değerlerinden ekonomik büyümeye doğru yine pozitif bir etki olduğunu vurgulamışlardır.

\begin{tabular}{|c|c|c|c|c|}
\hline $\begin{array}{l}\text { Gövdere } \\
\text { Can, } 2015\end{array}$ & $1970-2014$ & $\begin{array}{l}\text { - Enerji Tüketimi } \\
\text { - GSYH }\end{array}$ & $\begin{array}{l}\text { - Eşbütünleşme testi } \\
\text { • Dinamik EKK yöntemi }\end{array}$ & $\begin{array}{l}\text { Enerji tüketimi ve GSYH ikilisinde uzun dönemli } \\
\text { bir ilişki bulmuşlardır. }\end{array}$ \\
\hline $\begin{array}{l}\text { Bhattacharya ve } \\
\text { ark., } 2016\end{array}$ & 1991-2012 & $\begin{array}{l}\text { - Enerji Tüketimi } \\
\text { - GSYH }\end{array}$ & $\begin{array}{l}\text { - Panel Birim Kök Testi } \\
\text { - Panel Eşbütünleşme }\end{array}$ & $\begin{array}{l}\text { Seçilmiş } 38 \text { ülkeden } 23 \text { 'ünde enerji tüketiminden } \\
\text { GSYH'ye doğru bir pozitif etki olduğu sonucuna } \\
\text { varmışlardır. }\end{array}$ \\
\hline
\end{tabular}


Bu çalışmada Türkiye ekonomisine ilişkin 1970-2015 dönemine ait yıllık enerji veri setleri kullanılarak reel GSYH ve enerji tüketimi üzerine inceleme yapılmıştır.

Çalışma dört bölümden oluşmaktadır. Birinci bölümde, teorik incelemelere ve çalışmanın amacına yer verilmiştir. Çalışmanın ikinci bölümünde, analize dahil edilen iki değişkeni konu alan önceki çalışmalar bir araya getirilmiştir. Üçüncü bölümde, birim kök test sınamalarına, eşbütünleşme testi ve Granger nedensellik test yöntemi uygulamasına yer verilmiştir. Çalışmanın dördüncü ve son kısmında ise en küçük kareler yöntemi kullanılarak model denklemi oluşturulmuştur. Ayrıca söz konusu değişkenlerin nedenselliği bulunarak sonuçları yorumlanmış, enerji kaynaklarının ekonomik büyümedeki yerine değinilmiş ve bazı politika önerilerine yer verilmiştir. Araştırma konusu değişkenler için literatür genelinde, enerji tüketimi olarak birincil enerji tüketim verileri kullanılmıştır. Bu çalışmada ise birincil enerji tüketim verilerinin yanı sıra ikincil enerji tüketim verileri de veri setlerine dahil edilmiş ve 45 yıllık uzun bir dönem aralı̆̆ 1 seçilerek araştırma yapılmıştır.

\section{Materyal ve Metot}

Bu çalışmada Türkiye ekonomisine ilişkin 1970-2015 dönemine ait yıllık veriler Dünya Bankası istatistik veri tabanı (Dünya istatistik veri tabanı, 2020) ve Türkiye Enerji Denge Tabloları'ndan (Türkiye enerji denge tabloları, 2019) temin edilmiş olup kullanılan değişken ve tanımları Tablo 2'de belirtilmektedir.

Reel GSYH 2010 yılı baz olarak seçilmiştir. Bağımsız değişken ise birincil ve ikincil enerji tüketimlerinin genel toplamı olacak şekilde ifade edilmektedir (TÜKETIM). GSYH, Amerika Birleşik Devletleri (ABD) fiyatlarıyla "milyar \$", TÜKETIM ise "bin Ton Eşdeğer Petrol (TEP)" olarak alınmıştır.

Bu çalışmada durağanlığı araştırmak için Genişletilmiş Dickey Fuller (ADF) Birim Kök Testi, Philips-Perron (PP) Birim Kök Testi, nedensellik ilişkisini belirlemek için ise Granger Nedensellik Testi kullanılmıştır (K1sakürek, 2019).

\section{Genişletilmiş Dickey Fuller (ADF) Birim Kök Testi}

Ekonometrik olarak araştırılan analizlerde kullanılan değişkenlerle ilgili kuvvetli ve mantıklı ilişkiler tespit edebilmek için bu değişkenleri oluşturan veri setlerinin durağan olup yani birim kök içermemesi şarttır (Kutlar, 2000).

Birim kökü test etmek için genel olarak Augmented Dickey Fuller (ADF) testi kullanılmaktadır (Dickey ve Fuller, 1979; Dickey ve Fuller, 1989).

$$
\mathrm{V}_{\mathrm{t}}=\beta_{0}+\beta_{1} \mathrm{~V}_{\mathrm{t}-1}+\sum_{\mathrm{i}-1}^{\mathrm{m}} \alpha_{\mathrm{i}} \Delta_{\mathrm{t}-\mathrm{i}}+\mathrm{Y}_{\mathrm{t}}+\varepsilon_{\mathrm{t}}
$$

Denklem (1) ele alındığında $\Delta$; ele alınan değişken için fark, $\mathrm{V}_{\mathrm{t}}$; ilgili değişkeni, m; denkleme ilave edilen bağımlı değiş̧ken gecikmelerini $\beta$ ve $\alpha$; parametreleri, $\mathrm{Y}_{\mathrm{t}}$; gözlenen değişkeni, $\varepsilon_{\mathrm{t}}$ ise hata terimini temsil etmektedir. Genişletilmiş birim kök testi değişken katsayısı $(\delta)$ 'nın sayısal olarak sıfır olup olmadığını ölçmektedir. Bu birim kök testi istatistik t değerinin MacKinnon (Mackinnon, 1996) kritik değeriyle olan kıyasına dayanmaktadır (Mucuk ve Uysal, 2009). 
Tablo 2. Model Veri Setinde Kullanılan Değişkenler ve Tanımlamaları

\begin{tabular}{ccc}
\hline Değişken & Tanımlama & Kaynak \\
\hline LOGGSYH & Reel GSYH'nin logaritması & Dünya Bankası İstatistik Veri Tabanı \\
LOGTUKETIM & $\begin{array}{c}\text { Toplam Enerji Tüketiminin } \\
\text { Logaritması }\end{array}$ & Türkiye Enerji Denge Tabloları \\
\hline
\end{tabular}

Tablo 3’teki ADF (Dickey ve Fuller, 1979; Dickey ve Fuller, 1989) ve PP birim kök testi (Phillips ve Perron, 1988) neticesinde kullanılan değişken veri setlerinin düzey seviyede olasılık değerleri 0,01 ve 0,05’ten küçük olduğu için durağan olmadığı görülmektedir. Dolayısıyla, tüketim ve GSYH değişkenleri için sabitli, sabitlitrendli modellerde birinci derece fark işlemi sonrasında durağandırlar sonucuna varılmaktadır.

Tablo 4'te kısıtlanmış eş bütünleşme testi sonuçları görülmektedir. Johensen (Johensen, 1988; Johensen, 1995) eşbütünleşme analizi sonucunda, iz değeri $(25,88787)$ kritik değerden $(15,49471)$ yüksek olması sebebiyle \%1 $(0,0010<0,01)$ anlamlılık düzeyinde anlamlıdır.

\section{Philips-Perron (PP) Birim Kök Testi}

Dickey-Fuller birim kök testinde rastgele hata değerlerinin sayımlama olarak normal dağılım gösterdiği, bağımsız, sabit bir ortalama ve bu ortalama etrafında dağılımı sabit olarak varsayılmaktadır.

P. Perron testi'nde (Perron, 1989) ise Dickey-Fuller testinde kabul edilen bu hata terimlerinin arasındaki hataların dağılımları ile alakalı yeni bir varsayımda bulunmaktadır (Dikmen, 2012).

$$
\begin{aligned}
& \Delta \mathrm{Y}_{\mathrm{t}}=\beta_{0}+\delta \mathrm{Y}_{\mathrm{t}-1}+\varepsilon_{\mathrm{t}} \\
& \Delta \mathrm{Y}_{\mathrm{t}}=\beta_{0}+\beta_{1} \mathrm{~T}+\delta \mathrm{Y}_{\mathrm{t}-1}+\varepsilon_{\mathrm{t}}
\end{aligned}
$$

Denklem (2-3) baz alınırsa, $Y_{t}$; gözlenen değişkeni, T; trendi, $\varepsilon_{t}$, hata terimini, $\beta$ ve $\delta$ simgeleri; parametreleri ifade etmektedir. PP testi'nin avantajı kullanıcının test regresyonu için bir gecikme uzunluğu belirtmek zorunda kalmamasıdır. $\delta$ katsayısının $\mathrm{t}$ istatistiği ile Mackinnon kritik değeri karşılaştırılır ve serinin durağanlık durumuna bakılır (Abdioğlu ve Terzi, 2009).

\section{Granger Nedensellik Testi}

Bir zaman serisindeki iki değişken arasındaki nedensellik araştırmasının bir yolu olarak, Granger (Granger, 1969) öncülüğ̈̈nde geliştirilmiştir. Araştırmalarda kullanılan değişkenlere ilişkin bu değişkenler arasındaki nedensellik yönünü ortaya koymaktadır ve en çok uygulanan teknik türüdür.

Granger nedensellik testi için Denklem (4) ve Denklem (5) kullanılmaktadır.

$$
\mathrm{Y}_{\mathrm{t}}=\mathrm{a}_{0} \sum_{\mathrm{i}=1}^{\mathrm{p}} \varnothing_{\mathrm{i}} \mathrm{Y}_{\mathrm{t}-\mathrm{i}} \sum_{\mathrm{i}=1}^{\mathrm{q}} \delta_{\mathrm{i}} \mathrm{X}_{\mathrm{t}-\mathrm{i}} \varepsilon_{\mathrm{t}}
$$




$$
X_{t}=\beta_{0}+\sum_{i=1}^{p} \pi_{i} X_{t-i}+\sum_{i=1}^{q} \lambda_{i} Y_{t-i}+\mu_{t}
$$

$\alpha$ ile $\beta$ katsayıları, sabit terimleri; $Y_{t}$ ve $X_{t}$ gözlenen değişkenleri; $\varepsilon_{t}$ ve $\mu_{t}$ hata terimini; $\varnothing, \varphi, \delta, \pi$ ile $\lambda$ sembolleri ise gecikmeli olarak elde edilen parametrelerin tahmin edilen katsayısını göstermektedir. Bunun yanı sıra $\mathrm{p}$ ile q katsayıları ise $\mathrm{X}$ serisi ile $\mathrm{Y}$ serisinin uygun gecikme uzunluğunu göstermektedir.

\section{Bulgular ve Tartışma}

Ekonomik büyüme göstergesi olan GSYH ham değerleri ile artan bir trend izlemektedir. Logaritmaları alınmış GSYH (loggsyh) değerleri, 1970-2015 y1lları arasında artan bir trende sahiptir. Aynı şekilde, logaritması alınmış enerji tüketim değerleri de bu zaman döneminde artan bir trende sahip olduğu görünmektedir. İlgili değişkenlere birinci fark işlemi uygulandığında durağanlaşmıştır. Düzey seviyede (loggsyh ve logtuketim) ve fark işlemi uygulandığındaki değerler Tablo 3 'te verilmiştir.

Tablo 3’teki ADF (Dickey ve Fuller, 1979; Dickey ve Fuller, 1989) ve PP (Phillips ve Perron, 1988) birim kök testi neticesinde kullanılan değişken veri setlerinin düzey seviyede olasılık değerleri 0,01 ve 0,05 'ten küçük olduğu için durağan olmadığı görülmektedir. Dolayısıyla, tüketim ve GSYH değişkenleri için sabitli, sabitlitrendli modellerde birinci derece fark işlemi sonrasında durağandırlar sonucuna varılmıştır. Tablo 4'te kısıtlanmış eşbütünleşme testi sonuçları görülmektedir. Johensen (Johensen, 1988; Johensen, 1995) eşbütünleşme analizi sonucunda, iz değeri $(25,88787)$ kritik değerden $(15,49471)$ yüksek olması sebebiyle \%1 $(0,0010<0,01)$ anlamlılık düzeyinde anlamlıdır.

Tablo 3. ADF ve PP Birim Kök Test Sonuçları

\begin{tabular}{|c|c|c|c|c|c|c|}
\hline & & & ADF Testi & & PP & \\
\hline & & & $t \mathbf{t}$ istatistik değeri & Olasılık değeri & $t$ istatistik değeri & Olasılık değeri \\
\hline \multirow{4}{*}{ LOGTUKETIM } & Sabitli & Düzeyde & $-0,466973$ & 0,8877 & $-0,554077$ & 0,8704 \\
\hline & & 1.fark & $-7,299399$ & $0,0000 *$ & $-13,23718$ & $0,0000 *$ \\
\hline & Sabitli-Trendli & Düzeyde & $-4,823774$ & $0,0017 *$ & $-4,888347$ & $0,0014 *$ \\
\hline & & 1.fark & $-7,210958$ & $0,0000^{*}$ & $-12,97876$ & $0,0000^{*}$ \\
\hline \multirow{4}{*}{ LOGGSYH } & Sabitli & Düzeyde & $-0,315665$ & 0,9147 & 0,115957 & 0,9635 \\
\hline & & 1.fark & $-4,956588$ & $0,0002 *$ & $-6,368712$ & $0,0000^{*}$ \\
\hline & Sabitli-Trendli & Düzeyde & $-2,008160$ & 0,5808 & $-2,746307$ & 0,2240 \\
\hline & & 1.fark & $-4,896275$ & $0,0014 *$ & $-6,310447$ & $0,0000 *$ \\
\hline
\end{tabular}

Tablo 4. Kısıtlanmış Eşbütünleşme Derecesi Testi (İz)

\begin{tabular}{ccccc} 
r & Özdeğer & İz İstatiği & 0.05 Kritik Değer & Olasılık Değeri** $^{*}$ \\
\hline $0^{*}$ & 0,460093 & 25,88787 & 15,49471 & 0,0010 \\
1 & 0,000920 & 0,000808 & 3,841466 & 0,9785 \\
\hline
\end{tabular}

Not: İz testine göre; 0,05 seviyesinde bir tane eşbütünleşik denklemi (r) içerir.

* Hipotezin 0,05 seviyesinde reddedildiği anlamına gelir.

**MacKinnon-H.-Michelis(1999) olasılık değerleri. 
Tablo 5. Hata Terimlerinin Durağanlığı

\begin{tabular}{|c|c|c|c|c|}
\hline & & & t-istatistik & Olasılık* \\
\hline Augmented Dickey Fuller Test istatistiği & & & $-2,752272$ & 0,0070 \\
\hline \multirow[t]{3}{*}{ Kritik test değeri } & \%1 seviyesinde & & $-2,617364$ & \\
\hline & \%5 seviyesinde & & $-1,948313$ & \\
\hline & $\% 10$ seviyesinde & & $-1,612229$ & \\
\hline \multicolumn{5}{|l|}{ * MacKinnon(1996) tek taraflı p-değerleri } \\
\hline Değerler & Katsayı & $\begin{array}{l}\text { Standart } \\
\text { hata }\end{array}$ & t-istatistik & Olasılık* \\
\hline HATATERİMLERI(-1) & $-0,289497$ & 0,105185 & $-2,752272$ & 0,0086 \\
\hline $\mathrm{R}^{2}$ & 0,146849 & & & \\
\hline Düzeltilmiş $\mathrm{R}^{2}$ & 0,146849 & & & \\
\hline
\end{tabular}

Uzun dönemde Türkiye ekonomisinde enerji tüketimi (LOGTUKETIM) ve GSYH (LOGGSYH) değişkenleri arasında eşbütünleşik bir ilişkinin varlığını mevcut kılmaktadır. Tablo 5'te hata terimlerinin durağanlığına baktığımızda düzey (level) ve sabitsiz trendsiz (none) modelde olasılık değeri 0,0070 olup 0,01 değerinden küçük olup \%1 düzeyinde anlamlıdır.

Hata düzeltme modeline baktığımızda, hata düzeltme değerimizin katsayısı -1 ile 0 aralığında olmalıdır şartını sağlamaktadır. Hata terimi değeri olan -0,290634 değeri, kısa dönemde yaşanan şok etkisinden kaynaklı ortaya çıkan uzun dönem denge farkının yılda aşağı yukarı \%29 oranda karşıladığını ifade etmektedir.

Tablo 6'da bağımlı değişken LOGGSYH için bağımsız değişken olan LOGTUKETIM in olasılık değeri 0'dır ve 0,05 'ten küçüktür yani \%5 düzeyinde anlamlıdır. Buradan tüketim değerleri gayri safi yurtiçi hasıla (GSYH)'nın nedeni olduğu görülmektedir.

Bağımlı değişken LOGTUKETIM için bağımsız değişken olan LOGGSYH in olasılık değeri 0,2377 olup 0,05'ten büyük yani \%5 düzeyinde anlamlı değildir. Bu durumda gayri safi yurt içi hasıla tüketimin bir nedeni olmadı̆̆ını göstermektedir (Kısakürek, 2019).

Gerekli tahminleri yapabilmek için aşağıda Denklem 6'ya göre EViews programında modelleme (Denklem 78) kurulmuştur.

$$
\begin{aligned}
& \beta_{1}+\beta_{2} \log \left(x_{2}\right)+\beta_{x} \log \left(x_{3}\right)+\ldots .+\beta_{n} \log \left(x_{n}\right) \\
& \text { LOGGSYH }=C(1)+C(2) * \text { LOGTUKETIM } \\
& \text { LOGGSYH }=4,11166996863+0,603796781828 * \text { LOGTUKETIM }+ \\
& 0,332218517987 * \text { LOGTUKETIM }(-1)
\end{aligned}
$$

Modelde kullanılan değişkenlerden kimin regresyona ne kadar katkı sağladığını t-istatistik değeri ile anlaşılabilmektedir. Mutlakça büyük olan t-istatistik değerine sahip parametre, analizde en büyük paya sahip olan değişkendir. Tablo 7’ye baktığımızda önem sırasına göre katsayıdan sonra sırasıyla tüketim değerleri ile bir önceki tüketim değerlerinin etkili olduğunu söyleyebiliriz. 
Tablo 6. Granger Nedensellik Test Sonuçları

\begin{tabular}{lccc}
\hline Bağımlı değişken LOGGSYH & & \\
\hline \multirow{2}{*}{ Dişlanan } & ki-kare & df & olasılık \\
LOGTUKETIM & 29,26132 & 3 & 0,0000 \\
All & 29,26132 & 3 & 0,0000 \\
& & & \\
\hline Bağımlı değişken LOGTUKETIM & & \\
\hline \multirow{2}{*}{ Dişlanan } & ki-kare & df & olasılık \\
LOGGSYH & 4,229773 & 3 & 0,2377 \\
All & 4,229773 & 3 & 0,2377 \\
\hline
\end{tabular}

Tablo 7. Toplulaştırılmış Denklemlerin Sıradan En Küçük Kareler Yöntemi (EKK) Sonuçları

\begin{tabular}{|c|c|c|c|c|}
\hline Değişken & Katsayı & Standart Hata & t-istatistiği & Olasılık \\
\hline $\mathrm{C}$ & $-4,111670$ & 0,196808 & $-20,89179$ & 0,0000 \\
\hline LOGTUKETIM & 0,603797 & 0,126170 & 4,785575 & 0,0000 \\
\hline LOGTUKETIM(-1) & 0,332219 & 0,125740 & 2,642111 & 0,0115 \\
\hline $\mathrm{R}^{2}$ & 0,984357 & \multicolumn{2}{|c|}{ Bağımlı değiskenin ortalaması } & 5,986657 \\
\hline Düzeltilmiş $\mathrm{R}^{2}$ & 0,983612 & \multicolumn{2}{|c|}{ Bağımlı değişkenin std. sapması } & 0,547453 \\
\hline Regresyonun Std.Hatas1 & 0,070082 & \multicolumn{2}{|c|}{ F-istatistik } & 1321,452 \\
\hline Hataların kareleri top. & 0,206285 & \multirow{2}{*}{\multicolumn{2}{|c|}{ Olasıl1k (F-istatistik) }} & 0,000000 \\
\hline Durbin-Watson ist. & 1,871626 & & & \\
\hline
\end{tabular}

Modelin tamamının anlamlılı̆ modelimiz anlamlıdır yorumu yapabiliriz. Logtuketım 'in katsayısı $=0,603797$, $\mathrm{p}$-değeri $=0<0,05$ 'tir ve yine $\mathrm{H}_{0}{ }^{\prime} ı$ reddedilmesi sonucunda istatistiksel oranda \%5 seviyesinde parametre bir anlam ifade etmektedir.

Modelde kullanılan değişkenlerden regresyona ne kadar katkı sağladığı t-istatistik değerine bakılarak anlaşılmaktadır. Tablo 7'de mutlakça büyük olan t-istatistik değerine sahip parametre, analizde büyük etkiye sahiptir. Modelin olasılık değeri (F-istatistiği) 0,05 ’ten küçük olup \%5 seviyesinde anlamlı olup, $\mathrm{R}^{2}$ değeri 0,98'dir. Bu değere belirlilik katsayısı denilmektedir ve bağımlı değişkendeki değişimin bağımsız değişkeni ne kadar etkilediğini göstermektedir. $\mathrm{R}^{2}$ regresyonda oldukça önemlidir ve değerinin 1'e yakın olması, bağımsız değişkenin modeldeki bağımlı değişkenin tamamına yakınını açıkladığı söylenebilir (Yavuz, 2009).

\section{Sonuçlar}

Çalışmada gerçekleştirilen regresyon analizi sonucunda enerji tüketimi ile ekonomik büyüme sembolü olarak kullanılan reel gayri safi yurtiçi hasıla (GSYH) arasında pozitif yönlü kuvvetli bir ilişki mevcuttur. Enerji tüketimindeki 1 birimlik bir değişim ekonomik büyümede \%0,60’lık değişim (artış-azalış) sağlamaktadır. Ayrıca, gerçekleştirilen Granger nedensellik testine göre, tüketim değerleri GSYH'nin nedeni olarak belirlenmiştir. Elde ettiğimiz bu sonuçlar (Şengül ve Tuncer, 2006; Tsani, 2010; Yanar ve Kerimoğlu, 2011; Pao ve ark., 2014 ve Bhattacharya ve ark., 2016) ile tutarlıdır. (Şengül ve Tuncer, 2006) ve (Yanar ve Kerimoğlu, 2011) Türkiye için enerji kullanımından GSYH'ye tek yönlü nedensellik tespit etmişlerdir. (Tsani, 2010), Yunanistan, Pao ve ark., (2014) Brezilya ve Bhattacharya ve ark., (2016) 23 ülke için enerji tüketiminden ekonomik büyümeye doğru işleyen tek yönlü nedensellik bulmuşlardır. 
Bağımsız değişken olan enerji tüketiminin bağımlı değişken olan GSYH değişkenini açıklama gücü oldukça kuvvetlidir. Durbin-Watson değeri $(1,87), 2$ 'ye yakın olması otokorelasyonun olmadığını gösterir. Logaritması alınmış tüketimdeki yüzde birlik artış logaritması alınmış gayri safi yurtiçi hasıla $\mathrm{R}^{2}$ değeri de regresyon analizinin başarı oranını göstermektedir. Bu kapsamda çalışmada kullanılan yöntemin $\mathrm{R}^{2}$ değeri 0,98 bulunmuştur. Ekonomik büyüme ve enerji tüketim ilişkisi incelendiğinde, enerji tüketiminden ekonomik büyümeye doğru tek yönlü bir ilişki vardır.

Çalışmada elde edilen uzun dönemli denge ilişkisine göre, enerji tüketiminin iktisadi büyümede son derece etkili bir parametre olduğu görülmektedir. Enerji kullanımında büyük ölçüde dışa bağımlı olan Türkiye için enerji kaynakları çeşitlendirilmeli ve yenilenebilir enerjiye yatırımlar arttırılmalıdır; ülkedeki üretim çeşitliliğinin sağlanması ve arttırılması, iktisadi büyümenin devamı ve gerekli olan enerjinin sürekliliğiyle sağlanabilir. Ayrıca mevcut enerji tüketimi için verimlilik arttırıcı yollar aranmalıdır.

\section{Teşekkür}

$\mathrm{Bu}$ çalışma, Osmaniye Korkut Ata Üniversitesi Bilimsel Araştırma Projeleri Birimi tarafından OKÜBAP2019-PT3-014 Numaralı proje kapsamında desteklenmiştir. Desteklerinden dolayı OKÜBAP'a teşekkür ederiz.

\section{Çıkar Çatışması Beyanı}

Makale yazarları aralarında herhangi bir çıkar çatışması olmadığını beyan ederler.

\section{Araştırmacıların Katkı Oranı Beyan Özeti}

Yazarlar makaleye eşit oranda katkı sağlamış olduklarını beyan ederler.

\section{Kaynakça}

Abdioğlu Z., Terzi H. Enflasyon ve bütçe açıkları ilişkisi: Tanzi ve Patinkin etkisi. Atatürk Üniversitesi İ.İ.B.F. Dergisi 2009; 23(2): 195-211.

Aslan A. Energy consumption and GDP: The strong relationship in OECD countries. Energy Sources 2013; 8(4): 339-345.

Bhattacharya M., Paramati SR., Ozturk I., Bhattacharya S. The effect of renewable energy consumption on economic growth: Evidence from top 38 countries. Applied Energy 2016; 162: 733-741.

Demirbaş M., Türkay H., Türkoğlu M. Petrol fiyatlarındaki değişmelerin Türkiye'nin cari açı̆̆ı üzerine etkisinin analizi. Süleyman Demirel Üniversitesi İ.İ.B.F Dergisi 2009; 14(3): 289-299.

Dickey D., Fuller WA. Distribution of the estimators for autoregressive time series with a unit root. Journal of the American Statistical Association 1979; 74: 427-431.

Dickey D., Fuller WA. Likelihood ratio statistics for autoregressive time series with a unit root. Econometrica 1989; 49: 1057-1072.

Dikmen N. Ekonometri temel kavramlar ve uygulamalar. Bursa: Dora Basım Yayım Dağıtım; 2012.

Dünya istatistik veri tabanı. https://data.worldbank.org/country/turkey?locale=tr (Erişim 15.08.2020). 
Global energy statistical yearbook 2020. https://yearbook.enerdata.net/total-energy/world-consumptionstatistics.html (Erişim 15.01.2021).

Granger CWJ. Investigating causal relations by econometric and cross- spectral method. Econometrica 1969; 37(3): 424-438.

Gövdere B., Can M. Enerji tüketimi ve ekonomik büyüme ilişkisi: Türkiye örnekleminde eşbütünleşme analizi. Uluslararası İktisadi ve İdari Bilimler Dergisi 2015; 1(2): 101-114.

Johansen S. Statistical analysis of cointegration vectors. Journal of Economic Dynamics and Control 1988; 12(2-3): 231-254.

Johansen S. Likelihood-based inference in cointegrated vector autoregressive models. New York: Oxford University Press; 1995.

Kısakürek T. Türkiye için enerji tüketimi ve ekonomik büyüme ilişkisinin incelenmesi. Osmaniye Korkut Ata Üniversitesi Fen Bilimleri Enstitüsü Yüksek Lisans Tezi, sayfa no:53, Osmaniye, Türkiye, 2019.

Korkmaz Ö., Develi A. Türkiye’de birincil enerji kullanımı, üretimi ve gayri safi yurt içi hasıla (GSYİH) arasındaki ilişki. Dokuz Eylül Üniversitesi İktisadi ve İdari Bilimler Fakültesi Dergisi 2012; 27(2): 125.

Kraft J., Kraft A. On the relationship between energy and GNP. Journal of Energy and Development 1978; 3: 401-403.

Kutlar A. Ekonometrik zaman serileri teori ve uygulama. Ankara: Gazi Kitabevi; 2000.

Mackinnon JG. Numerical distribution functions for unit root and cointegration tests. Journal of Applied Econometrics 1996; 11: 601-618.

Mucuk M., Uysal D. Türkiye ekonomisinde enerji tüketimi ve ekonomik büyüme. Maliye Dergisi 2009; 157: 108-109.

Öztürk S., Saygın S. 1973. Petrol krizinin ekonomiye etkileri ve stagflasyon olgusu. Balkan Sosyal Bilimler Dergisi 2017; 6(12): 1-11.

Pao HT., Li YY., Fu HC. Causality relationship between energy consumption and economic growth in Brazil. Smart Grid and Renewable Energy 2014; 5(8): 198-205.

Perron P. The great crash, the oil price shock, and the unit root hypothesis. Econometrica 1989; 57(6): 13611401.

Phillips PCB., Perron P. Testing for a unit root in time series regressions. Biometrika 1988; 75: 335-346.

Shakeel M., Iqbal MM., Majeed MT. Energy consumption, trade and GDP: a case study of South Asian countries. Munich Personal RePEc Archive (MPRA), 2013; 57677.

Şengül S., Tuncer, İ. Türkiye'de enerji tüketimi ve ekonomik büyüme:1960-2000. İktisat İşletme ve Finans 2006; 21(242): 69-80.

TEİAŞ. Türkiye Elektrik İletim Anonim Şirketi. Nisan 2021 kurulu güç raporu. https://www.teias.gov.tr/trTR/kurulu-guc-raporlari (Erişim 11.05.2021).

Tsani ZS. Energy consumption and economic growth: a causality analysis for Greece. Energy Economics 2010; 32: 582-590. 
Türkiye enerji denge tabloları. https://www.dunyaenerji.org.tr/turkiye-enerji-denge-tablolari/ (Erişim 05.07.2019).

Yalta AT. Analyzing energy consumption and GDP nexus using maximum entropy bootstrap: the case of Turkey. Energy Economics 2011; 33: 453-460.

Yanar, R., Kerimoğlu, G. Türkiye'de enerji tüketimi, ekonomik büyüme ve cari açık ilişkisi. Ekonomi Bilimleri Dergisi 2011; 3(2): 191-201. 